\title{
Preoperative and Postoperative Approaches to Gastroesophageal Cancer: What is All the Fuss About
}

\author{
Lucy X. Ma, MD ${ }^{1, *}$; Elan D. Panov, MD ${ }^{1,{ }^{*}}$; Michael J. Allen, MD'; Gail E. Darling, MD²; Jonathan C. Yeung, MD²; \\ Carol J. Swallow, MD ${ }^{3}$; Savtaj S. Brar, MD³; Rebecca K. Wong, MD ${ }^{4}$; Patrick Veit-Haibach, MD ${ }^{5}$; \\ Sangeetha N. Kalimuthu, MD; Eric X. Chen, MD; Raymond W. Jang, ${ }^{1} D^{1}$; and Elena Elimova, MD
}

\begin{abstract}
Gastroesophageal cancers carry poor prognoses, and are a leading cause of cancer-related morbidity and mortality worldwide. Even in those with resectable disease, more than half of patients treated with surgery alone experience disease recurrence. Multimodality approaches using preoperative and postoperative chemotherapy and/or radiotherapy have been established, resulting in incremental improvements in outcomes. Globally, there is no standardized approach, and treatment varies with geographic location. The question remains of how to select the optimal perioperative treatment that will maximize benefit for patients while avoiding toxicities from unnecessary therapies. This article reviews currently available evidence supporting preoperative and postoperative therapy in gastroesophageal cancers, with an emphasis on recent practice-changing trials and ongoing areas of investigation, including the role of immune checkpoint inhibition and biomarker-guided treatment.
\end{abstract}

J Natl Compr Canc Netw 2022;20(2):193-202 doi: $10.6004 /$ jnccn.2021.7118

\footnotetext{
${ }^{1}$ Division of Medical Oncology and Hematology, Princess Margaret Cancer Centre; ${ }^{2}$ Division of Thoracic Surgery, Department of Surgery, Toronto General Hospital; ${ }^{3}$ Department of Surgical Oncology, Princess Margaret Cancer Centre; ${ }^{4}$ Department of Radiation Oncology, Princess Margaret Cancer Centre; and ${ }^{5}$ Joint Department Medical Imaging, and ${ }^{6}$ Department of Pathology, Laboratory Medicine Program, University Health Network, University of Toronto, Toronto, Canada.

*These authors contributed equally to this work and are co-first authors.
}

Gastroesophageal cancers are a heterogeneous group of cancers that develop insidiously and carry poor prognoses. ${ }^{1,2}$ Worldwide, gastric adenocarcinoma and esophageal cancer represent the fourth and sixth most common causes of cancer-related death, respectively. ${ }^{3}$ Surgery is the primary curative treatment modality, except for esophageal squamous cell carcinomas (SCCs), for which definitive chemoradiotherapy (CRT) can be considered. ${ }^{4,5}$ Despite advances in surgical techniques, prognosis with surgery alone remains poor, with 5 -year overall survival (OS) rates ranging from $30 \%$ to $40 \%{ }^{6,7}$ Multimodality approaches incorporating preoperative and postoperative chemotherapy and/or radiotherapy have been established; however, there is no standardized approach and notable geographic variation in treatment exists. Upfront surgery with adjuvant chemotherapy is favored in Asian countries, whereas neoadjuvant or perioperative treatment is preferred in Europe and North America. ${ }^{8-11}$ The perioperative approach to gastroesophageal cancers is further complicated by the fact that esophageal cancers comprise 2 different histologies, each with different molecular characteristics. The genomic profile of esophageal SCC has been shown to share more similarities to other aerodigestive SCCs, whereas that of esophageal adenocarcinomas resembles the chromosomally unstable variant of gastric adenocarcinoma. ${ }^{12,13}$ Although in clinical trials gastroesophageal junction (GEJ) cancers have traditionally been grouped with either esophageal or gastric cancer depending on the tumor's anatomic Siewert classification, molecular profiling studies suggest that basing treatment on histology may be more appropriate.

The high morbidity of surgery often limits the ability to deliver treatment postoperatively, highlighting the need for novel strategies to either develop more active preoperative treatment or more tolerable postoperative therapies. This article reviews currently available evidence

See page 100 for related commentary. 
supporting preoperative and postoperative approaches in gastroesophageal cancer, with an emphasis on recent practice-changing trials and ongoing areas of investigation, including the role of immune checkpoint inhibition and biomarker-driven approaches to treatment.

\section{Approaches to Resectable Gastric Cancer}

\section{Postoperative Chemotherapy}

Given the high risk of recurrence following surgical resection, several randomized phase III trials investigating

\section{Table 1. Phase III Trials Supporting Postoperative Therapy in Resectable Gastric and GEJ Cancer}

\begin{tabular}{|c|c|c|c|c|c|c|c|}
\hline Trial & Year & Phase & Patients & Investigational Arm & Control & Survival Outcomes & HR \\
\hline \multicolumn{8}{|c|}{ Postoperative chemotherapy } \\
\hline ACTS-GC 8,14 & 2007 & III & $\begin{array}{l}\text { Japan: resected } \\
\text { gastric } \\
\text { adenocarcinoma } \\
\text { Stage II-IIIB } \\
\text { R0 resection and D2 } \\
\text { lymphadenectomy } \\
\text { required } \\
(\mathrm{N}=1,059)\end{array}$ & $\begin{array}{l}\text { Adjuvant S-1 daily, } \\
4 \text { wk on and } 2 \text { wk } \\
\text { off, for } 12 \text { mo }\end{array}$ & Surgery only & $\begin{array}{l}\text { 5-y OS: } 71.7 \% \text { vs } \\
\text { 61.1\% (control) } \\
5-y \text { RFS: } 65.4 \% \text { vs } \\
53.1 \% \text { (control) }\end{array}$ & $\begin{array}{l}\mathrm{HR} \text { for OS, } 0.669(95 \% \mathrm{Cl}, \\
0.540-0.828) \\
\text { HR for RFS, } 0.653(95 \% \mathrm{Cl}, \\
0.537-0.793)\end{array}$ \\
\hline CLASSIC $^{9,15}$ & 2012 & III & $\begin{array}{l}\text { South Korea, China, } \\
\text { Taiwan: resected } \\
\text { gastric } \\
\text { adenocarcinoma } \\
\text { Stage II-IIIB } \\
\text { R0 resection and D2 } \\
\text { lymphadenectomy } \\
\text { required } \\
(\mathrm{N}=1,035)\end{array}$ & $\begin{array}{l}\text { Adjuvant } \\
\text { capecitabine and } \\
\text { oxaliplatin every } 3 \text { wk } \\
\text { for } 8 \text { cycles }\end{array}$ & Surgery only & $\begin{array}{l}\text { 5-y OS: } 78 \% \text { vs } 69 \% \\
\text { (control) } \\
5-y \text { DFS: } 68 \% \text { vs } 53 \% \\
\text { (control) }\end{array}$ & $\begin{array}{l}\text { HR for OS, } 0.66(95 \% \mathrm{Cl} \text {, } \\
0.51-0.85 ; P=.0015) \\
\text { HR for DFS, } 0.58(95 \% \mathrm{Cl} \text {, } \\
0.47-0.72 ; P<.0001)\end{array}$ \\
\hline \multicolumn{8}{|c|}{ Postoperative CRT } \\
\hline INT-0116 ${ }^{18,19}$ & 2001 & III & $\begin{array}{l}\text { United States: } \\
\text { resected gastric or } \\
\text { GEJ adenocarcinoma } \\
\text { Stage IB-IVA } \\
\text { RO resection } \\
\text { required DO-2 } \\
\text { lymphadenectomies } \\
\text { included } \\
(\mathrm{N}=556)\end{array}$ & $\begin{array}{l}\text { Adjuvant CRT } \\
\text { Adjuvant 5-FU + } \\
\text { leucovorin (days 1-5) } \\
\text { for } 1 \text { cycle; RT ( } 45 \text { Gy) } \\
\text { with concurrent 5-FU } \\
+ \text { leucovorin (first } 4 \\
\text { and last } 3 \text { days of RT); } \\
2 \text { cycles of 5-FU + } \\
\text { leucovorin (days 1-5) }\end{array}$ & Surgery only & $\begin{array}{l}\text { 3-y OS: } 50 \% \text { vs } 41 \% \\
\text { (control) } \\
\text { 3-y RFS: } 48 \% \text { vs } 31 \% \\
\text { (control) }\end{array}$ & $\begin{array}{l}\mathrm{HR} \text { for OS, } 1.32(95 \% \mathrm{Cl} \\
1.10-1.60 ; P=.0046) \\
\text { HR for RFS, } 1.51(95 \% \mathrm{Cl} \text {, } \\
1.25-1.83 ; P<.001)\end{array}$ \\
\hline ARTIST ${ }^{21,22}$ & 2012 & III & $\begin{array}{l}\text { South Korea: } \\
\text { resected gastric } \\
\text { adenocarcinoma } \\
\text { Stage IB-IVA } \\
\text { R0 resection and D2 } \\
\text { lymphadenectomy } \\
\text { required } \\
(\mathrm{N}=458)\end{array}$ & $\begin{array}{l}\text { Adjuvant CRT: XP } \\
\text { every } 3 \text { wk for } 2 \\
\text { cycles; RT ( } 45 \text { Gy) } \\
\text { with concurrent } \\
\text { capecitabine (daily); } \\
2 \text { cycles of XP }\end{array}$ & $\begin{array}{l}\text { Adjuvant } \\
\text { chemotherapy: } \\
\text { XP every } 3 \text { wk, for } \\
6 \text { cycles }\end{array}$ & $\begin{array}{l}\text { 5-y OS: } 75 \% \text { (CRT) } \\
\text { vs } 73 \% \text { (XP) } \\
\text { 3-y DFS: } 78.2 \% \text { (CRT) } \\
\text { vs } 74.2 \% \text { (XP) } \\
\text { 3-y DFS in node- } \\
\text { positive: } 77.5 \% \text { (CRT) } \\
\text { vs } 72.3 \% \text { (XP) }\end{array}$ & $\begin{array}{l}\text { HR for OS, } 1.130(95 \% \mathrm{Cl}, \\
0.775-1.647 ; P=.5272) \\
\text { HR for DFS, } 0.74(95 \% \mathrm{Cl} \\
0.52-1.05 ; P=.0922)\end{array}$ \\
\hline CALGB $80101^{20}$ & 2017 & III & $\begin{array}{l}\text { United States: } \\
\text { resected gastric or } \\
\text { Siewert III GEJ } \\
\text { adenocarcinoma } \\
\text { Stage IB-IVA } \\
\text { R0 resection } \\
\text { required D1-2 } \\
\text { lymphadenectomies } \\
\text { included } \\
(\mathrm{N}=546)\end{array}$ & $\begin{array}{l}\text { Adjuvant ECF; } \\
\text { RT ( } 45 \text { Gy) with } \\
\text { concurrent } 5-\mathrm{FU} \\
\text { (daily); } 2 \text { additional } \\
\text { cycles of ECF }\end{array}$ & $\begin{array}{l}\text { Adjuvant } 5 \text {-FU (days } \\
1-5) \text { for } 1 \text { cycle; } \\
\text { RT ( } 45 \text { Gy) with } \\
\text { concurrent } 5 \text {-FU } \\
\text { (daily); } 2 \text { additional } \\
\text { cycles of } 5 \text {-FU (days } \\
1-5 \text { ) }\end{array}$ & $\begin{array}{l}5-y \text { OS: } 44 \% \text { (ECF) } \\
\text { vs } 44 \%(5-F U) \\
5-y \text { DFS: } 37 \% \text { (ECF) } \\
\text { vs } 39 \%(5-F U)\end{array}$ & $\begin{array}{l}\text { HR for OS, } 0.98(95 \% \mathrm{Cl} \text {, } \\
0.78-1.24 ; P=.69) \\
\text { HR for DFS, } 0.96(95 \% \mathrm{Cl} \text {, } \\
0.77-1.20 ; P=.94)\end{array}$ \\
\hline ARTIST $2^{23}$ & 2020 & III & $\begin{array}{l}\text { South Korea: } \\
\text { resected gastric } \\
\text { adenocarcinoma } \\
\text { Stage II-IVA, lymph } \\
\text { node positive } \\
\text { R0 resection and D2 } \\
\text { lymphadenectomy } \\
\text { required } \\
(\mathrm{N}=546)\end{array}$ & $\begin{array}{l}\text { SOXRT: adjuvant } \\
\text { SOX for } 2 \text { cycles; } \\
\text { RT ( } 45 \text { Gy) with } \\
\text { concurrent S-1 (daily); } \\
4 \text { additional cycles of } \\
\text { SOX }\end{array}$ & $\begin{array}{l}\text { SOX: adjuvant S-1 } \\
\text { (days } 1-14 \text { ) and } \\
\text { oxaliplatin (day 1) } \\
\text { every } 3 \text { wk for } 8 \text { cycles } \\
\text { S-1: adjuvant S-1 daily, } \\
4 \text { wk on and } 2 \text { wk off } \\
\text { for } 8 \text { cycles }\end{array}$ & $\begin{array}{l}\text { 3-y DFS: } \\
72.8 \% \text { (SOXRT) vs } \\
74.3 \% \text { (SOX) vs } \\
64.8 \% \text { (S-1) }\end{array}$ & $\begin{array}{l}\text { HR for DFS: SOXRT vs SOX, } \\
0.971(95 \% \mathrm{Cl}, 0.663-1.421 ; \\
P=.879) \\
\text { HR for DFS: SOXRT vs S-1; } \\
0.724(95 \% \mathrm{Cl}, 0.507-1.032 ; \\
P=.074) \\
\text { HR for DFS: SOX vs S-1, } 0.693 \\
(95 \% \mathrm{Cl}, 0.409-0.987 ; P=.042)\end{array}$ \\
\hline
\end{tabular}

Abbreviations: CRT, chemoradiotherapy; DFS, disease-free survival; ECF, epirubicin/cisplatin/5-FU; GEJ, gastroesophageal junction; HR, hazard ratio; OS, overall survival; RFS, relapse-free survival; RT, radiotherapy; S-1, oral chemotherapy comprised of tegafur, gimeracil, and oteracil; SOX, S-1/oxaliplatin; SOXRT, S-1/oxaliplatin and radiotherapy; XP, capecitabine/cisplatin. 
adjuvant chemotherapy have been conducted (Table 1). The Japanese ACTS-GC trial assigned 1,059 patients following gastrectomy and D2 lymphadenectomy to receive adjuvant S-1 for 12 months or surgery alone. ${ }^{8}$ There was a significant survival advantage with $\mathrm{S}-1$, with superior relapse-free survival (RFS) (65.4\% vs 53.1\%; hazard ratio [HR], 0.653) and OS (71.7\% vs $61.1 \%$; HR, 0.669) with S-1 at 5 years. ${ }^{14}$ The CLASSIC study, conducted in South Korea, China, and Taiwan, investigated adjuvant chemotherapy (8 cycles of capecitabine and oxaliplatin) following D2 gastrectomy compared with surgery alone. ${ }^{9}$ The chemotherapy group had improved disease-free survival (DFS) $(68 \%$ vs $53 \%$; HR, 0.58$)$ and OS $(78 \%$ vs $69 \%$; HR, $0.66)$ at 5 years, although with high rates of toxicity (56\% with $\geq 1$ grade 3 or 4 adverse events). ${ }^{15}$ Based on these trials, surgery with adjuvant chemotherapy is the preferred approach for resectable gastric cancer in Asian countries.

\section{Postoperative CRT}

Treatment strategies involving postoperative CRT have also been explored, based on the observation that locoregional recurrence occurred in up to $40 \%$ to $65 \%$ of patients after curative-intent gastric resection in North America (Table 1). ${ }^{16,17}$ The INT-0116 study randomized 556 patients with gastric or GEJ adenocarcinoma to postoperative CRT (1 cycle of fluorouracil/leucovorin, then 45 Gy of radiation + fluorouracil/leucovorin, followed by 2 cycles of fluorouracil/leucovorin) or observation following surgical resection. ${ }^{18}$ Rates of grade 3 and 4 toxicity with CRT were high (41\% and $32 \%$, respectively) and only $64 \%$ of patients completed the planned treatment. Although the study reported significant improvement in RFS and OS with CRT, primarily driven by decreased local recurrences, a major limitation of INT-0116 was that only $10 \%$ of patients underwent D2 lymphadenectomy, whereas $36 \%$ had a D1 and 54\% had a D0 dissection, calling into question whether the benefits of CRT would still be seen if all patients had received optimal surgery. ${ }^{19}$ The follow-up CALGB 80101 study showed that changing the postoperative CRT regimen to epirubicin/cisplatin/infusional fluorouracil (ECF) did not improve OS, although ECF was better tolerated. ${ }^{20}$

The ARTIST trial sought to elucidate the role of CRT in 458 patients who underwent curative resection with D2 lymph node dissection..$^{21}$ Following surgery, patients were randomized to receive chemotherapy alone (6 cycles of capecitabine + cisplatin [XP]) or chemotherapy + CRT ( 2 cycles of XP, 45 Gy of radiation with concurrent capecitabine, 2 further cycles of XP). Overall, no DFS benefit was seen with the addition of CRT (3-year DFS, $78.2 \%$ CRT vs $74.2 \%$ chemotherapy; $P=.0862$ ). A subgroup analysis suggested DFS improvement in those with pathologic lymph node positivity, prompting the subsequent ARTIST 2 study. ${ }^{22}$ In ARTIST 2, 546 patients with D2-resected nodepositive gastric cancer were randomized to 1 of 3 arms: S-1 for 1 year, S-1 + oxaliplatin (SOX) for 6 months, or SOX + CRT (SOXRT). ${ }^{23}$ The trial was terminated prematurely, and did not show a DFS difference between SOX and SOXRT (3-year DFS, 74.3\% vs 72.8\%, respectively; HR, 0.971).

Taken together, these studies do not support the routine use of postoperative CRT in patients who have undergone D2 lymphadenectomy.

\section{Perioperative Chemotherapy}

Another strategy is the use of perioperative chemotherapy (Table 2). The UK Medical Research Council (MRC) MAGIC trial was a landmark trial that randomized 503 patients with adenocarcinoma of the stomach (74\%), GEJ (11.5\%), or lower esophagus (14.5\%) to receive 3 cycles of preoperative and postoperative ECF or surgery alone. ${ }^{24}$ The perioperative chemotherapy arm had significantly improved progression-free survival (PFS) (HR, 0.66; $P<.001$ ) and OS (HR, 0.75; $P=.009$ ), with a $13 \%$ improvement in 5-year OS. This benefit was seen despite only $42 \%$ of patients in the perioperative arm completing all 6 cycles of chemotherapy. The French FNCLCC ACCORD-07/ FFCD 9703 trial of perioperative cisplatin and fluorouracil similarly found significant improvement in DFS (HR, 0.65; $P=.003)$ and OS (HR, 0.69; $P=.02$ ) compared with surgery alone. ${ }^{25}$ Again, only $23 \%$ completed all postoperative therapy.

The FLOT4-AIO study was a practice-changing trial comparing the perioperative ECF regimen used in the MAGIC trial with 4 cycles of preoperative and postoperative FLOT (fluorouracil/leucovorin/oxaliplatin/docetaxel). ${ }^{11}$ In total, 716 patients with gastric $(44 \%)$ or GEJ adenocarcinoma (23\% Siewert 1; $32 \%$ Siewert 2 or 3 ) were included. FLOT significantly improved PFS (HR, $0.75 ; P=.004$ ) and OS (HR, $0.77 ; P=.012$ ). Consistent with previous trials, only $60 \%$ of patients in the FLOT group started postoperative chemotherapy, and only $46 \%$ completed all 8 cycles of FLOT.

Taken together, these studies show significant survival benefit with the use of perioperative chemotherapy, with FLOT being the preferred regimen. Notably, completing planned chemotherapy following surgery was a challenge in each study. To address this issue, the EORTC 40954 trial investigated a neoadjuvant chemotherapy approach using cisplatin, fluorouracil and leucovorin; however, the study was closed early due to poor accrual and failed to demonstrate a survival benefit. ${ }^{26}$ Given the challenges of treating these patients postoperatively, and lack of success using preoperative chemotherapy only, strategies are needed to either improve neoadjuvant therapies or develop more tolerable postoperative regimens.

\section{How to Improve Perioperative Treatment}

Even in patients who receive perioperative FLOT, the estimated 5-year OS rate is only $45 \%$, highlighting the need for further improvements to treatment efficacies. The CRITICS study examined the addition of postoperative 


\begin{tabular}{|c|c|c|c|c|c|c|c|}
\hline Trial & Year & Phase & Patients & Investigational Arm & Control & Survival Outcomes & HR \\
\hline \multicolumn{8}{|c|}{ Pre- and perioperative chemotherapy } \\
\hline MAGIC ${ }^{24}$ & 2006 & III & $\begin{array}{l}\text { United Kingdom: } \\
\text { esophageal, GEJ } \\
\text { and gastric } \\
\text { adenocarcinoma } \\
\text { Stage II-III } \\
(\mathrm{N}=503)\end{array}$ & $\begin{array}{l}\text { Neoadjuvant ECF } \\
\text { every } 3 \text { wk for } 3 \\
\text { cycles, surgery; } \\
\text { adjuvant ECF for } \\
3 \text { cycles }\end{array}$ & Surgery only & $\begin{array}{l}5-y \text { OS: } 36.3 \% \text { vs } \\
23 \% \text { (control) }\end{array}$ & $\begin{array}{l}\text { HR for OS, } 0.75 \\
(95 \% \mathrm{Cl}, 0.60-0.93 \text {; } \\
P=.009) \\
\text { HR for PFS, } 0.66 \\
(95 \% \mathrm{Cl}, 0.53-0.81 \text {; } \\
P<.001)\end{array}$ \\
\hline EORTC $40954^{26}$ & 2010 & III & $\begin{array}{l}\text { Europe: gastric and } \\
\text { Siewert I-III GEJ } \\
\text { adenocarcinoma } \\
\text { Stage III-IVA } \\
\text { D1-2 } \\
\text { lymphadenectomies } \\
\text { included } \\
(\mathrm{N}=144)\end{array}$ & $\begin{array}{l}\text { Neoadjuvant } 5 \text {-FU } \\
\text { (days } 1,8,15,22, \\
29,36) \text { and cisplatin } \\
\text { (days } 1,15,29 \text { ) }\end{array}$ & Surgery alone & $\begin{array}{l}2-y \text { OS: } 72.7 \% \text { vs } \\
69.9 \% \text { (control) }\end{array}$ & $\begin{array}{l}\text { HR for OS, } 0.84 \\
(95 \% \mathrm{Cl}, 0.52-1.35 ; \\
P=.466) \\
\text { HR for PFS, } 0.76 \\
(95 \% \mathrm{Cl}, 0.49-1.16 \text {; } \\
P=.20)\end{array}$ \\
\hline $\begin{array}{l}\text { FNCLCC ACCORD- } \\
07 / \text { FFCD } 9703^{25}\end{array}$ & 2011 & III & $\begin{array}{l}\text { France: esophageal, } \\
\text { GEJ and gastric } \\
\text { adenocarcinoma } \\
\text { Stage II-III } \\
(\mathrm{N}=224)\end{array}$ & $\begin{array}{l}\text { Neoadjuvant 5-FU } \\
\text { (days } 1-5 \text { ) and } \\
\text { cisplatin (day } 1 \text { ) } \\
\text { every } 3 \text { wk, for } 2-3 \\
\text { cycles; surgery; } \\
\text { adjuvant } 5 \text {-FU (days } \\
1-5 \text { ) and cisplatin } \\
\text { (day } 1 \text { ) every } 3 \text { wk, } \\
\text { for } 3-4 \text { cycles (up to } \\
6 \text { total cycles) }\end{array}$ & Surgery only & $\begin{array}{l}\text { 5-y OS: } 38 \% \text { vs } 24 \% \\
\text { (control) } \\
5 \text {-y DFS: } 34 \% \text { vs } 19 \% \\
\text { (control) }\end{array}$ & $\begin{array}{l}\text { HR for OS, } 0.69 \\
(95 \% \mathrm{Cl}, 0.50-0.95 ; \\
P=.02) \\
\text { HR for DFS, } 0.65 \\
(95 \% \mathrm{Cl}, 0.48-0.89 ; \\
P=.003)\end{array}$ \\
\hline FLOT4-AIO ${ }^{11}$ & 2019 & III & $\begin{array}{l}\text { Germany: gastric or } \\
\text { Siewert GEJ } \\
\text { adenocarcinoma } \\
\text { Stage IB-III } \\
(\mathrm{N}=716)\end{array}$ & $\begin{array}{l}\text { Neoadjuvant FLOT } \\
\text { every } 2 \text { wk for } 4 \\
\text { cycles; surgery; } \\
\text { adjuvant FLOT for } \\
4 \text { cycles }\end{array}$ & $\begin{array}{l}\text { Neoadjuvant ECX or } \\
\text { ECF for } 3 \text { cycles; } \\
\text { surgery; adjuvant } \\
\text { ECX or ECF for } \\
3 \text { cycles }\end{array}$ & $\begin{array}{l}\text { 5-y OS: } 45 \% \text { (FLOT) } \\
\text { vs } 36 \% \text { (ECX/ECF) }\end{array}$ & $\begin{array}{l}\text { HR for OS, } 0.77 \\
(95 \% \mathrm{Cl}, 0.63-0.94 ; \\
P=.012) \\
\text { HR for DFS, } 0.75 \\
(95 \% \mathrm{Cl}, 0.62-0.91 ; \\
P=.0036)\end{array}$ \\
\hline \multicolumn{8}{|c|}{ Perioperative chemotherapy with pre- or postoperative CRT } \\
\hline CRITICS $^{27}$ & 2018 & III & $\begin{array}{l}\text { Europe: gastric and } \\
\text { Siewert III GEJ } \\
\text { adenocarcinoma } \\
\text { Stage IB-IVA } \\
(\mathrm{N}=788)\end{array}$ & $\begin{array}{l}\text { CRT: Neoadjuvant } \\
\text { ECX for } 3 \text { cycles; } \\
\text { surgery; adjuvant } \\
\text { radiation ( } 45 \mathrm{~Gy} \text { ) } \\
\text { with concurrent } \\
\text { cisplatin (weekly } \times \\
\text { 5) and capecitabine } \\
\text { (daily) }\end{array}$ & $\begin{array}{l}\text { Chemotherapy: } \\
\text { ECX for } 3 \text { cycles; } \\
\text { surgery; adjuvant } \\
\text { ECX for } 3 \text { cycles }\end{array}$ & $\begin{array}{l}\text { 5-y OS: } 40 \% \text { (CRT) } \\
\text { vs 42\% } \\
\text { (chemotherapy) } \\
5-y \text { EFS: } 38 \% \text { (CRT) } \\
\text { vs 39\% } \\
\text { (chemotherapy) }\end{array}$ & $\begin{array}{l}\text { HR for OS, } 1.01 \\
(95 \% \mathrm{Cl}, 0.84-1.22 \text {; } \\
P=.90) \\
\text { HR for EFS, } 0.99 \\
(95 \% \mathrm{Cl}, 0.82-1.19 ; \\
P=.92)\end{array}$ \\
\hline
\end{tabular}

Abbreviations: CRT, chemoradiotherapy; DFS, disease-free survival; ECF, epirubicin/cisplatin/5-FU; ECX, epirubicin/cisplatin/capecitabine; EFS, event-free survival; FLOT, fluorouracil/leucovorin/oxaliplatin/docetaxel; GEJ, gastroesophageal junction; HR, hazard ratio; OS, overall survival; PFS, progression-free survival; RFS, relapse-free survival; RT, radiotherapy.

CRT to perioperative chemotherapy. ${ }^{27}$ A total of 788 patients (83\% gastric, $17 \%$ Siewert 2 or 3 GEJ adenocarcinoma) underwent 3 cycles of preoperative chemotherapy (epirubicin, cisplatin, or oxaliplatin, and capecitabine; Table 2) followed by surgery and went on to receive either 3 cycles of the same chemotherapy or 45 Gy of radiotherapy with concurrent cisplatin and capecitabine. There was no difference in OS between the 2 cohorts (43 vs 37 months, respectively; HR, 1.01; $P=.90$ ).

The ongoing TOPGEAR trial is examining the addition of neoadjuvant CRT to perioperative chemotherapy and will provide insight about whether adding another treatment modality in the neoadjuvant setting when patients are better able to tolerate therapy will improve outcomes (Table 3 ) ${ }^{28}$ CRITICS II is another ongoing trial studying 3 preoperative approaches: chemotherapy alone versus chemotherapy followed by CRT versus CRT alone (Table 3). ${ }^{29}$

\section{Approaches to Esophageal Cancer}

\section{Management of Esophageal SCC}

Definitive CRT can be considered for curative-intent treatment of esophageal SCC, leaving surgery for salvage. The few randomized trials comparing definitive CRT with trimodality (CRT followed by surgery) treatment have not shown a significant OS difference, although a trimodality approach may improve locoregional control (Table 4). ${ }^{4,5,30}$ 


\section{Table 3. Ongoing Trials Investigating Novel Approaches to Resectable Gastroesophageal Cancer}

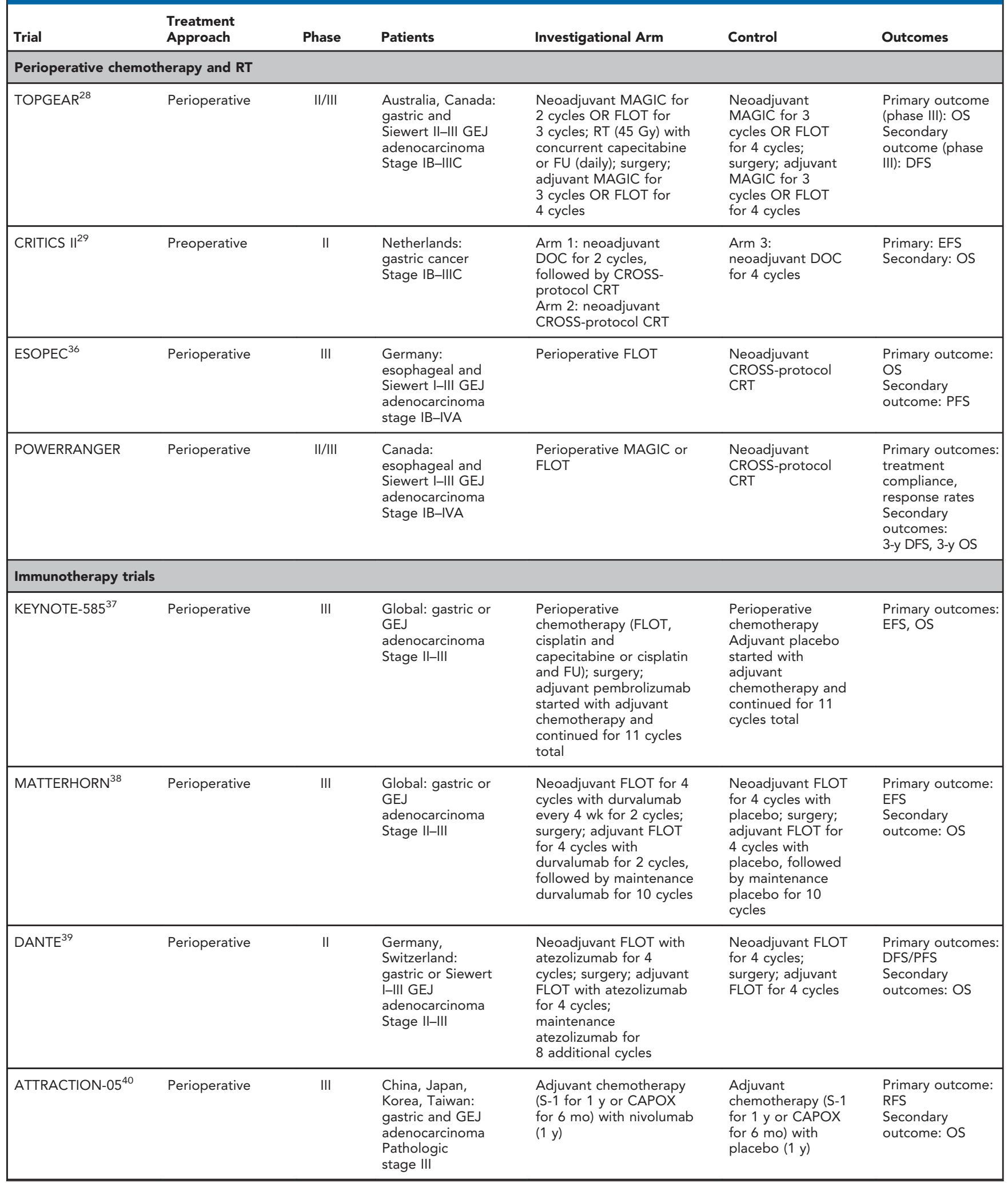


Table 3. Ongoing Trials Investigating Novel Approaches to Resectable Gastroesophageal Cancer (cont.)

\begin{tabular}{|c|c|c|c|c|c|c|}
\hline Trial & $\begin{array}{l}\text { Treatment } \\
\text { Approach }\end{array}$ & Phase & Patients & Investigational Arm & Control & Outcomes \\
\hline \multicolumn{7}{|c|}{ Immunotherapy trials (cont.) } \\
\hline EA2174 ${ }^{41}$ & Perioperative & $\| / I I I$ & $\begin{array}{l}\text { United States: } \\
\text { esophageal or } \\
\text { Siewert I-II GEJ } \\
\text { adenocarcinoma } \\
\text { Stage II-III }\end{array}$ & $\begin{array}{l}\text { Arm A: neoadjuvant RT } \\
\text { ( } 50.4 \text { Gy) with concurrent } \\
\text { carboplatin AUC } 2 \text { and } \\
\text { paclitaxel (weekly for } 5 \\
\text { wk), and nivolumab (days } \\
1,15) ; \text { surgery; adjuvant } \\
\text { nivolumab for } 12 \text { cycles } \\
\text { Arm B: neoadjuvant RT } \\
\text { (50.4 Gy) with concurrent } \\
\text { carboplatin AUC } 2 \text { and } \\
\text { paclitaxel (weekly for } \\
5 \text { wk), and nivolumab } \\
\text { (days } 1,15) ; \text { surgery; } \\
\text { adjuvant nivolumab for } \\
12 \text { cycles with } \\
\text { ipilimumab on cycles } 1 \text {, } \\
4,7,10\end{array}$ & $\begin{array}{l}\text { Neoadjuvant CRT } \\
\text { only }\end{array}$ & $\begin{array}{l}\text { Primary outcomes: } \\
\text { pCR rate, DFS } \\
\text { Secondary } \\
\text { outcome: OS }\end{array}$ \\
\hline
\end{tabular}

Abbreviations: AUC, area under the curve; CAPEOX, capecitabine/oxaliplatin; CRT, chemoradiotherapy; DFS, disease-free survival; DOC, docetaxel/ oxaliplatin/capecitabine; EFS, event-free survival; FLOT, fluorouracil/leucovorin/oxaliplatin/docetaxel; FU, fluorouracil; GEJ, gastroesophageal junction; OS, overall survival; pCR, partial complete response; PFS, progression-free survival; RFS, relapse-free survival; RT, radiotherapy.

Aside from definitive CRT trials, esophageal SCC has generally been grouped with esophageal adenocarcinoma in clinical trials. Based on the differing molecular characteristics suggesting that these are distinct diseases, future trials should separate the 2 histologies.

\section{Neoadjuvant CRT}

The pivotal CROSS trial established the benefit of neoadjuvant CRT in esophageal and GEJ cancer, randomizing 366 patients (75\% adenocarcinoma, 23\% SCC) to receive preoperative CRT (41.4 Gy) with weekly carboplatin and paclitaxel followed by resection, or surgery alone ${ }^{10}$ (Table 4). Neoadjuvant CRT was well tolerated, with $91 \%$ completing the full treatment regimen and no significant increase in postoperative morbidity compared with surgery alone. The CRT arm had significantly improved OS over surgery alone (HR, $0.657 ; P=.003)$, with absolute 5 - and 10 -year OS benefit of $14 \%$ ( $47 \%$ vs $33 \%$ ) and $13 \%$ ( $38 \%$ vs $25 \%$ ), respectively. ${ }^{31,32}$ A greater magnitude of benefit was seen in the SCC subgroup, although those with adenocarcinoma derived benefit as well. As a result, the CROSS protocol became the standard of care for resectable esophageal cancer in North America.

\section{Adjuvant Immunotherapy}

Although the use of multimodality treatment has achieved incremental progress in improving outcomes in gastroesophageal cancers, up to half of patients will experience cancer recurrence, highlighting the persisting unmet need for better therapies. CheckMate 577 was a global trial investigating a 1-year course of adjuvant nivolumab compared with surveillance in patients with resected esophageal $(60 \%)$ or GEJ $(40 \%)$ cancer who had residual pathologic disease after neoadjuvant CRT and surgery. ${ }^{33}$ Of the 794 patients, $71 \%$ had adenocarcinoma and $29 \%$ SCC. A significant DFS improvement was seen with nivolumab, with a median DFS of 22.4 versus 11.0 months (HR, 0.69; $P<.001)$. Nivolumab was well tolerated, with no reduction in health-related quality of life. ${ }^{34}$ Although OS data are pending, we anticipate adjuvant nivolumab will yield a significant OS benefit, given the doubling in DFS. This trial establishes adjuvant nivolumab as a new standard of care in this patient population.

\section{Remaining Questions and Future Approaches}

Neoadjuvant CRT Versus Perioperative Chemotherapy in GEJ Adenocarcinoma

Although both perioperative chemotherapy and preoperative CRT have been established as standard of care in resectable gastroesophageal cancer, a subset of patients will fit the criteria for both approaches. The optimal strategy for these patients remains a crucial question that several trials have been designed to address.

The Neo-AEGIS study presented at the 2021 ASCO Annual Meeting randomized 377 patients with esophageal or GEJ adenocarcinoma to receive perioperative chemotherapy (85\% MAGIC, 15\% FLOT) or preoperative CRT with CROSS. ${ }^{35}$ Initially designed as a superiority trial, this was modified to a noninferiority analysis with a margin of $5 \%$. Survival was similar between the 2 arms, meeting noninferiority criteria, with 3 -year OS of $56 \%$ with CROSS and $57 \%$ with perioperative chemotherapy (HR, 1.02; 95\% CI, 0.74-1.42). Outcomes including rates of pathologic complete response, R0 resection, and nodal 


\begin{tabular}{|c|c|c|c|c|c|c|c|}
\hline Trial & Year & Phase & Patients & Investigational Arm & Control & Survival Outcomes & HR \\
\hline Stahl et al ${ }^{4,30}$ & 2005 & III & $\begin{array}{l}\text { Germany: upper or } \\
\text { mid third } \\
\text { esophageal SCC } \\
\text { Stage II-III } \\
(\mathrm{N}=172)\end{array}$ & $\begin{array}{l}\text { CRT and surgery: } \\
\text { neoadjuvant 5-FU, etoposide, } \\
\text { cisplatin for } 3 \text { cycles; RT } \\
\text { ( } 40 \text { Gy) with concurrent } \\
\text { cisplatin and etoposide } \\
\text { (days 2-8); surgery }\end{array}$ & $\begin{array}{l}\text { Definitive CRT: } \\
\text { neoadjuvant 5-FU, } \\
\text { etoposide, cisplatin } \\
\text { for } 3 \text { cycles; RT } \\
\text { (40 Gy) with } \\
\text { concurrent cisplatin } \\
\text { and etoposide (days } \\
\text { 2-8); RT to complete } \\
65 \text { Gy }\end{array}$ & $\begin{array}{l}\text { 2-y OS: } 39.9 \% \\
\text { (surgery) vs } 35.4 \% \\
\text { (definitive CRT) } \\
\text { 2-y PFS: } 64.3 \% \\
\text { (surgery) vs } 40.7 \% \\
\text { (definitive CRT) } \\
\end{array}$ & $\begin{array}{l}\text { OS log-rank test for } \\
\text { equivalence } P<.05 \\
\text { HR for PFS, } 2.1 \\
\text { (definitive CRT vs } \\
\text { surgery) }(95 \% \mathrm{Cl} \text {, } \\
1.3-3.5 ; P=.003 \text { ) }\end{array}$ \\
\hline FFCD $9102^{5}$ & 2007 & III & $\begin{array}{l}\text { France: thoracic } \\
\text { esophageal SCC } \\
(88.8 \%) \text { or } \\
\text { adenocarcinoma } \\
(11.2 \%) \\
\text { Stage II-III } \\
(\mathrm{N}=259)\end{array}$ & $\begin{array}{l}\text { CRT and surgery: } \\
\text { neoadjuvant RT ( } 46 \text { Gy) with } \\
2 \text { cycles concurrent cisplatin } \\
\text { (day } 1-5,22-26 \text { ) and } 5-\mathrm{FU} \\
\text { (day } 1-5,22-26 \text { ); surgery }\end{array}$ & $\begin{array}{l}\text { Definitive CRT: } \\
\text { RT (46 Gy) with } 2 \\
\text { cycles concurrent } \\
\text { cisplatin (day 1-5, } \\
22-26 \text { ) and 5-FU } \\
\text { (day 1-5, 22-26); } \\
20 \text { Gy (to complete } \\
\text { total } 66 \text { Gy) with } 3 \\
\text { cycles cisplatin and } \\
5-F U\end{array}$ & $\begin{array}{l}\text { 2-y OS: } 33.6 \% \\
\text { (surgery) vs } 39.8 \% \\
\text { (definitive CRT) } \\
2-y \text { local control: } \\
66.4 \% \text { (surgery) vs } \\
57 \% \text { (definitive CRT) }\end{array}$ & $\begin{array}{l}\text { HR for OS (definitive } \\
\text { CRT vs surgery), } \\
0.90 ; P=.44\end{array}$ \\
\hline \multicolumn{8}{|l|}{ Preoperative CRT } \\
\hline CROSS $^{10,31,32}$ & 2012 & III & $\begin{array}{l}\text { Netherlands: } \\
\text { esophageal or } \\
\text { Siewert I-III GEJ } \\
\text { adenocarcinoma, } \\
\text { SCC, or LCUD } \\
\text { Stage IB-IIIB } \\
(\mathrm{N}=368)\end{array}$ & $\begin{array}{l}\text { Neoadjuvant CRT: RT } \\
\text { ( } 41.1 \text { Gy) with concurrent } \\
\text { carboplatin AUC } 2 \text { and } \\
\text { paclitaxel (both given once } \\
\text { per week for } 5 \text { wk) }\end{array}$ & Surgery alone & $\begin{array}{l}\text { 5-y OS: } 47 \% \text { vs } 33 \% \\
\text { (control) } \\
\text { 5-y PFS: } 44 \% \text { vs } 27 \% \\
\text { (control) } \\
10-y \text { OS: } 38 \% \text { vs } \\
25 \% \text { (control) }\end{array}$ & $\begin{array}{l}\text { HR for OS, } 0.657 \\
(95 \% \mathrm{Cl} \\
0.495-0.871 ; \\
P=.003) \\
\text { HR for PFS, } 0.498 \\
(95 \% \mathrm{Cl} \\
0.357-0.693 \\
P<.001)\end{array}$ \\
\hline Neo-AEGIS ${ }^{35}$ & 2021 & III & $\begin{array}{l}\text { Europe: esophageal } \\
\text { or Siewert I-II GEJ } \\
\text { adenocarcinoma } \\
\text { Stage IB-IIIB } \\
(\mathrm{N}=377)\end{array}$ & $\begin{array}{l}\text { Neoadjuvant CROSS-protocol } \\
\text { CRT }\end{array}$ & $\begin{array}{l}\text { Perioperative } \\
\text { ECX/ECF (MAGIC) } \\
\text { or FLOT }\end{array}$ & $\begin{array}{l}\text { 3-y OS: } 56 \% \\
\text { (CROSS) vs } 57 \% \\
\text { (MAGIC/FLOT) }\end{array}$ & $\begin{array}{l}\text { HR for OS, } 1.02 \\
(95 \% \mathrm{Cl}, 0.74-1.42)\end{array}$ \\
\hline
\end{tabular}

Abbreviations: 5-FU, 5-fluorouracil; AUC, area under the curve; CRT, chemoradiotherapy; DFS, disease-free survival; ECF, epirubicin/cisplatin/5-FU; ECX, epirubicin/cisplatin/capecitabine; FLOT, fluorouracil/leucovorin/oxaliplatin/docetaxel; GEJ, gastroesophageal junction; HR, hazard ratio; LCUD, large cell undifferentiated carcinoma; OS, overall survival; PFS, progression-free survival; SCC, squamous cell carcinoma; RT, radiotherapy.

downstaging favored the CROSS arm. Overall, this study showed that either approach is likely reasonable, leaving clinicians to consider factors such as patient fitness, regimen tolerability, and differing patterns of recurrence with each approach to guide decision-making. Because this trial opened before the FLOT4-AIO results were available, most patients in the perioperative chemotherapy arm received ECF/ECX. Whether similar results would be achieved using FLOT is under investigation in the ongoing ESOPEC and POWERRANGER trials (Table 3). However, the target HR of 0.645 in ESOPEC will be difficult to meet, and it is uncertain whether this study will be able to adequately address this question. ${ }^{36}$

With the results of CheckMate 577, which included only patients who underwent neoadjuvant CRT, an additional question raised is the role of immune checkpoint inhibition in those receiving chemotherapy without radiation. The KEYNOTE-585 study is investigating the combination of pembrolizumab with perioperative chemotherapy. ${ }^{37}$ MATTERHORN is studying the addition of durvalumab to perioperative FLOT. ${ }^{38}$ The phase II DANTE trial is studying atezolizumab 
with perioperative FLOT. $^{39}$ These trials will help answer whether patients undergoing perioperative chemotherapy derive a similar benefit to that seen in CheckMate 577, or whether the abscopal effect induced by radiotherapy is a crucial component driving this benefit (Table 3).

Other trials of immunotherapy in resectable gastroesophageal cancer include ATTRACTION-05, a trial being conducted in Japan, Korea, and China investigating nivolumab in combination with adjuvant S-1 or CAPOX chemotherapy, as well as the phase II/III EA2174 study of preoperative CRT with nivolumab followed by postoperative nivolumab \pm ipilimumab (Table 3) ${ }^{40,41}$

\section{Biomarker-Driven Preoperative and \\ Postoperative Approaches}

In the era of personalized cancer medicine, predictive biomarkers are urgently needed to help determine the optimal treatment to maximize benefit for individual patients and to spare patients from toxicities of unnecessary therapies. In advanced gastroesophageal cancer, a higher combined positive score (CPS), a measure of PDL1 expression on tumor cells and tumor-associated immune cells, has been shown to predict benefit from immune checkpoint inhibitors. ${ }^{42}$ A post hoc analysis of PD-L1 CPS expression in CheckMate 577 has yielded similar findings, wherein adjuvant nivolumab was associated with significant DFS improvement in the CPS $\geq 5$ subgroup (HR, 0.62; 95\% CI, 0.45-0.83) but not necessarily in CPS $<5$ (HR, 0.89; 95\% CI, 0.65-1.22). ${ }^{33}$ Future studies should prospectively incorporate biomarker analysis into trial design, and further development of new predictive biomarkers is needed.

\section{Microsatellite Instability}

Patients with mismatch repair deficiency (dMMR) or high levels of microsatellite instability (MSI-H) represent another subgroup of patients who warrant special consideration in the perioperative setting. An individual patient data meta-analysis of the MAGIC, CLASSIC, ARTIST, and ITACA-S trials has suggested lack of benefit from perioperative or adjuvant chemotherapy in patients with MSIH/dMMR gastric cancer. ${ }^{43}$ In the advanced/metastatic setting, treatment with immune checkpoint inhibitors achieve response rates of $>55 \%$ in patients with MSI-H/ dMMR gastric cancer; however, there is a paucity of prospective data in patients treated with curative intent. ${ }^{44,45}$ Wherever possible, patients with resectable MSI-H/

\section{Table 5. Phase II/III Trials Investigating HER2 Inhibition in Resectable Gastroesophageal Cancer}

\begin{tabular}{|c|c|c|c|c|c|c|c|}
\hline Trial & Year & Phase & Patients & Investigational Arm & Control & Survival Outcomes & HR \\
\hline PETRARCA $^{51}$ & 2020 & II & $\begin{array}{l}\text { Germany: } \\
\text { esophageal, GEJ, } \\
\text { and gastric } \\
\text { adenocarcinoma } \\
\text { Stage IB-IVA } \\
(\mathrm{N}=81)\end{array}$ & $\begin{array}{l}\text { Neoadjuvant FLOT for } 4 \\
\text { cycles with trastuzumab and } \\
\text { pertuzumab every } 3 \text { wk; } \\
\text { surgery; adjuvant FLOT for } 4 \\
\text { cycles with trastuzumab and } \\
\text { pertuzumab every } 3 \text { wk; } \\
\text { maintenance trastuzumab and } \\
\text { pertuzumab for } 9 \text { more cycles }\end{array}$ & Perioperative FLOT & $\begin{array}{l}\text { 2-y OS: } 84 \% \text { vs } 77 \% \\
\text { (control) } \\
2-y \text { DFS: } 70 \% \text { vs } 54 \% \\
\text { (control) }\end{array}$ & $\begin{array}{l}\text { HR for DFS, } 0.58 \\
(95 \% \mathrm{Cl} \\
0.278-1.139 \\
P=.14)\end{array}$ \\
\hline RTOG $1010^{52}$ & 2020 & III & $\begin{array}{l}\text { United States: } \\
\text { esophageal or } \\
\text { Siewert I-II GEJ } \\
\text { adenocarcinoma, } \\
\text { HER2-amplified } \\
\text { Stage II-III } \\
(\mathrm{N}=203)\end{array}$ & $\begin{array}{l}\text { Neoadjuvant RT ( } 50.4 \text { Gy) } \\
\text { with concurrent carboplatin } \\
\text { AUC } 2 \text {, paclitaxel and } \\
\text { trastuzumab (weekly for } 6 \\
\text { wk); surgery; adjuvant } \\
\text { trastuzumab every } 3 \text { wk for } \\
13 \text { cycles }\end{array}$ & $\begin{array}{l}\text { Neoadjuvant RT } \\
\text { (50.4 Gy) with } \\
\text { concurrent } \\
\text { carboplatin AUC } 2 \\
\text { and paclitaxel } \\
\text { (weekly for } 6 \text { wk) }\end{array}$ & $\begin{array}{l}\text { 4-y DFS: } 33.1 \% \text { vs } \\
30.1 \% \text { (control) } \\
\text { Median OS: } 38.5 \text { vs } \\
38.9 \text { mo (control) }\end{array}$ & $\begin{array}{l}\text { HR for DFS, } 0.97 \\
(95 \% \mathrm{Cl}, 0.69-1.36 \text {; } \\
P=.85) \\
\text { HR for OS, } 1.01 \\
(95 \% \mathrm{Cl}, 0.69-1.47 \\
P=.95)\end{array}$ \\
\hline Ongoing Trial & Phase & \multicolumn{2}{|c|}{ Patients } & \multicolumn{3}{|c|}{ Investigational Arms } & Outcomes \\
\hline INNOVATION ${ }^{53}$ & II & \multicolumn{2}{|c|}{$\begin{array}{l}\text { Europe and Asia: } \\
\text { gastric and GEJ } \\
\text { adenocarcinoma, } \\
\text { HER2-overexpressed } \\
\text { (IHC or FISH) } \\
\text { Stage IB-III }\end{array}$} & $\begin{array}{l}\text { Arm 1: neoadjuvant } \\
\text { chemotherapy (any of } \\
\text { FLOT, cisplatin and } \\
\text { capecitabine, cisplatin and } \\
\text { fluorouracil, CAPOX, or } \\
\text { FOLFOX) with trastuzumab. } \\
\text { Adjuvant chemotherapy } \\
\text { with trastuzumab, followed } \\
\text { by maintenance } \\
\text { trastuzumab for a total of } \\
17 \text { cycles }\end{array}$ & $\begin{array}{l}\text { Arm 2: neoadjuvant } \\
\text { chemotherapy with } \\
\text { trastuzumab and } \\
\text { pertuzumab } \\
\text { Adjuvant } \\
\text { chemotherapy with } \\
\text { trastuzumab and } \\
\text { pertuzumab, } \\
\text { followed by } \\
\text { maintenance } \\
\text { trastuzumab and } \\
\text { pertuzumab for a } \\
\text { total of } 17 \text { cycles }\end{array}$ & $\begin{array}{l}\text { Arm 3: neoadjuvant } \\
\text { and adjuvant } \\
\text { chemotherapy only }\end{array}$ & $\begin{array}{l}\text { Primary outcome: } \\
\text { pathologic } \\
\text { response rate } \\
\text { Secondary } \\
\text { outcomes: PFS, } \\
\text { OS }\end{array}$ \\
\hline
\end{tabular}

Abbreviations: AUC, area under the curve; CAPOX, capecitabine/oxaliplatin; DFS, disease-free survival; FISH, fluorescence in situ hybridization; FLOT, fluorouracil/leucovorin/oxaliplatin/docetaxel; FOLFOX, 5-FU/leucovorin/oxaliplatin; GEJ, gastroesophageal junction; HR, hazard ratio; IHC, immunohistochemistry; OS, overall survival; PFS, progression-free survival; RT, radiotherapy. 
dMMR gastric cancer should be referred for clinical trials of chemotherapy omission or immune checkpoint inhibition strategies. Outside of a trial setting, patients should be individually counseled about the risks and potential benefits to come to an informed decision about cytotoxic chemotherapy.

\section{HER2 Inhibition}

In advanced or metastatic HER2-overexpressed or HER2amplified gastroesophageal adenocarcinoma, the addition of HER2-targeted therapy to chemotherapy is an established standard of care. ${ }^{46}$ HER2-directed therapies are under investigation in the curative-intent setting, with several single-arm phase II studies demonstrating the feasibility of incorporating HER2 blockade in the perioperative setting. ${ }^{47-50}$ Unfortunately, no randomized studies have demonstrated a survival benefit (Table 5). The phase II PETRARCA study found that adding trastuzumab and pertuzumab to perioperative FLOT increased the pathologic complete response rate; however, with increased toxicity and no significant DFS advantage, the trial closed before proceeding to phase III. ${ }^{51}$ Similarly, the phase III RTOG 1010 trial combining trastuzumab with preoperative CRT failed to show survival benefit. ${ }^{52}$ The ongoing phase II INNOVATION trial is studying the addition of trastuzumab \pm pertuzumab to perioperative chemotherapy. ${ }^{53}$ Given the results from previous studies, we anticipate this too will fail to improve survival. In the current treatment landscape of resectable gastroesophageal cancer, there is no role for HER2-targeted therapy in routine practice. Patients with HER2-positive cancers should be considered for clinical trials if available, or should otherwise receive the same treatment as HER2-negative patients.

\section{Conclusions}

The management of resectable gastroesophageal cancers has seen incremental changes over the past 2 decades, with clear evidence that multimodal approaches improve survival and that postoperative chemotherapy is difficult to complete, highlighting the need to develop either more active preoperative treatment or more tolerable postoperative therapies. The question of neoadjuvant versus perioperative therapy remains, and ongoing trials comparing the 2 strategies will provide further insight. Adjuvant immunotherapy following trimodality treatment has emerged as a practice-changing therapy, and OS results are eagerly awaited, as are results from perioperative immunotherapy trials. Prospective incorporation of biomarker analysis in the design of future clinical trials is encouraged to aid in the development of predictive biomarkers to guide decision-making and optimize treatment selection in the curative-intent setting.

Submitted November 8, 2021; accepted for publication November 30 2021.

Disclosures: Dr. Chen has disclosed participating in research for Zymeworks, Bristol-Myers Squibb, Merck, Novartis, Roche, and AstraZeneca; and serving as an advisory board member for Bayer and Taiho. Dr. Jang has disclosed participating in research and serving as a principal investigator for Merck; and serving as an advisory board member for Ipsen, Eisai, and Advanced Accelerator Applications/ Novartis. Dr. Elimova has disclosed participating in research for Bristol-Myers Squibb and Zymeworks; serving on a data safety monitoring board for Zymeworks; serving as an advisory board member and as a consultant for Zymeworks, BristolMyers Squibb, Adaptimmune Therapeutics, and BeiGene; and having a spouse employed by Merck. The remaining authors have disclosed that they have not received any financial consideration from any person or organization to support the preparation, analysis, results, or discussion of this article.

Correspondence: Elena Elimova, MD, Division of Medical Oncology and Hematology, Princess Margaret Cancer Centre, University Health Network, University of Toronto, 7-715 700 University Avenue, Toronto, Ontario, M5G 1X6, Canada. Email: Elena.Elimova@uhn.ca

\section{References}

1. Lagergren J, Smyth E, Cunningham D, et al. Oesophageal cancer. Lancet 2017;390:2383-2396.

2. Smyth EC, Nilsson M, Grabsch HI, et al. Gastric cancer. Lancet 2020;396 635-648.

3. Sung H, Ferlay J, Siegel RL, et al. Global Cancer Statistics 2020: GLOBOCAN estimates of incidence and mortality worldwide for 36 cancers in 185 countries. CA Cancer J Clin 2021;71:209-249.

4. Stahl M, Stuschke M, Lehmann N, et al. Chemoradiation with and without surgery in patients with locally advanced squamous cell carcinoma of the esophagus. J Clin Oncol 2005;23:2310-2317.

5. Bedenne L, Michel P, Bouché $O$, et al. Chemoradiation followed by surgery compared with chemoradiation alone in squamous cancer of the esophagus: FFCD 9102. J Clin Oncol 2007;25:1160-1168.

6. Cuschieri A, Weeden S, Fielding J, et al. Patient survival after D1 and D2 resections for gastric cancer: long-term results of the MRC randomized surgical trial. Br J Cancer 1999;79:1522-1530.

7. Rice TW, Rusch WW, Apperson-Hansen C, et al. Worldwide esophageal cancer collaboration. Dis Esophagus 2009;22:1-8.

8. Sakuramoto S, Sasako M, Yamaguchi T, et al. Adjuvant chemotherapy for gastric cancer with S-1, an oral fluoropyrimidine. N Engl J Med 2007; 357:1810-1820.

9. Bang YJ, Kim YW, Yang HK, et al. Adjuvant capecitabine and oxaliplatin for gastric cancer after D2 gastrectomy (CLASSIC): a phase 3 open-label, randomised controlled trial. Lancet 2012;379:315-321.

10. van Hagen $\mathrm{P}$, Hulshof $\mathrm{MC}$, van Lanschot JJ, et al. Preoperative chemoradiotherapy for esophageal or junctional cancer. N Engl J Med 2012;366:2074-2084.

11. Al-Batran SE, Homann N, Pauligk C, et al. Perioperative chemotherapy with fluorouracil plus leucovorin, oxaliplatin, and docetaxel versus fluorouracil or capecitabine plus cisplatin and epirubicin for locally advanced, resectable gastric or gastro-oesophageal junction adenocarcinoma (FLOT4): a randomised, phase 2/3 trial. Lancet 2019;393:1948-1957.

12. Cancer Genome Atlas Research Network. Integrated genomic characterization of oesophageal carcinoma. Nature 2017;541:169-175.

13. Cancer Genome Atlas Research Network. Comprehensive molecular characterization of gastric adenocarcinoma. Nature 2014;513:202-209.

14. Sasako M, Sakuramoto S, Katai H, et al. Five-year outcomes of a randomized phase III trial comparing adjuvant chemotherapy with S-1 versus surgery alone in stage II or III gastric cancer. J Clin Oncol 2011;29:4387-4393.

15. Noh SH, Park SR, Yang HK, et al. Adjuvant capecitabine plus oxaliplatin for gastric cancer after D2 gastrectomy (CLASSIC): 5-year follow-up of an open-label, randomised phase 3 trial. Lancet Oncol 2014;15:1389-1396.

16. Gunderson LL, Sosin H. Adenocarcinoma of the stomach: areas of failure in a re-operation series (second or symptomatic look) clinicopathologic correlation and implications for adjuvant therapy. Int J Radiat Oncol Biol Phys 1982;8:1-11.

17. Landry J, Tepper JE, Wood WC, et al. Patterns of failure following curative resection of gastric carcinoma. Int J Radiat Oncol Biol Phys 1990;19:1357-1362.

18. Macdonald JS, Smalley SR, Benedetti J, et al. Chemoradiotherapy after surgery compared with surgery alone for adenocarcinoma of 
the stomach or gastroesophageal junction. N Engl J Med 2001;345: 725-730.

19. Smalley SR, Benedetti JK, Haller DG, et al. Updated analysis of SWOGdirected intergroup study 0116: a phase III trial of adjuvant radiochemotherapy versus observation after curative gastric cancer resection. J Clin Oncol 2012;30:2327-2333.

20. Fuchs CS, Niedzwiecki D, Mamon HJ, et al. Adjuvant chemoradiotherapy with epirubicin, cisplatin, and fluorouracil compared with adjuvant chemoradiotherapy with fluorouracil and leucovorin after curative resection of gastric cancer: results from CALGB 80101 (Alliance). J Clin Oncol 2017;35:3671-3677.

21. Lee J, Lim DH, Kim S, et al. Phase III trial comparing capecitabine plus cisplatin versus capecitabine plus cisplatin with concurrent capecitabine radiotherapy in completely resected gastric cancer with D2 lymph node dissection: the ARTIST trial. J Clin Oncol 2012;30:268-273.

22. Park SH, Sohn TS, Lee J, et al. Phase III trial to compare adjuvant chemotherapy with capecitabine and cisplatin versus concurrent chemoradiotherapy in gastric cancer: final report of the adjuvant chemoradiotherapy in stomach tumors trial, including survival and subset analyses. J Clin Oncol 2015;33:3130-3136.

23. Park $\mathrm{SH}$, Lim DH, Sohn TS, et al. A randomized phase III trial comparing adjuvant single-agent S1, S-1 with oxaliplatin, and postoperative chemoradiation with S-1 and oxaliplatin in patients with node-positive gastric cancer after D2 resection: the ARTIST 2 trial. Ann Oncol 2021;32:368-374.

24. Cunningham $D$, Allum WH, Stenning SP, et al. Perioperative chemotherapy versus surgery alone for resectable gastroesophageal cancer. $\mathrm{N}$ Engl J Med 2006;355:11-20.

25. Ychou M, Boige V, Pignon JP, et al. Perioperative chemotherapy compared with surgery alone for resectable gastroesophageal adenocarcinoma: an FNCLCC and FFCD multicenter phase III trial. J Clin Oncol 2011;29:1715-1721.

26. Schuhmacher C, Gretschel S, Lordick F, et al. Neoadjuvant chemotherapy compared with surgery alone for locally advanced cancer of the stomach and cardia: European Organisation for Research and Treatment of Cancer randomized trial 40954. J Clin Oncol 2010;28:5210-5218.

27. Cats A, Jansen EPM, van Grieken NCT, et al. Chemotherapy versus chemoradiotherapy after surgery and preoperative chemotherapy for resectable gastric cancer (CRITICS): an international, open-label, randomised phase 3 trial. Lancet Oncol 2018;19:616-628.

28. Leong $T$, Smithers BM, Michael M, et al. TOPGEAR: a randomised phase III trial of perioperative ECF chemotherapy versus preoperative chemoradiation plus perioperative ECF chemotherapy for resectable gastric cancer (an international, Intergroup trial of the AGITG/TROG/EORTC/NCIC CTG). BMC Cancer 2015;15:532.

29. Slagter AE, Jansen EPM, van Laarhoven HWM, et al. CRITICS-II: a multicentre randomised phase II trial of neo-adjuvant chemotherapy followed by surgery versus neo-adjuvant chemotherapy and subsequent chemoradiotherapy followed by surgery versus neo-adjuvant chemoradiotherapy followed by surgery in resectable gastric cancer. BMC Cancer 2018;18:877.

30. Stahl $\mathrm{M}$, Wilke $\mathrm{H}$, Lehmann $\mathrm{N}$, et al. Long-term results of a phase III study investigating chemoradiation with and without surgery in locally advanced squamous cell carcinoma (LA-SCC) of the esophagus [abstract]. J Clin Oncol 2008;26(Suppl):Abstract 4530

31. Eyck BM, van Lanschot JJB, Hulshof MCCM, et al. Ten-year outcome of neoadjuvant chemoradiotherapy plus surgery for esophageal cancer: the randomized controlled CROSS trial. J Clin Oncol 2021;39:1995-2004.

32. Shapiro J, van Lanschot JJB, Hulshof MCCM, et al. Neoadjuvant chemoradiotherapy plus surgery versus surgery alone for oesophageal or junctional cancer (CROSS): long-term results of a randomised controlled trial. Lancet Oncol 2015;16:1090-1098.

33. Kelly RJ, Ajani JA, Kuzdzal J, et al. Adjuvant nivolumab in resected esophageal or gastroesophageal junction cancer. N Engl J Med 2021;384:1191-1203.

34. Cutsem EV, Singh P, Cleary JM, et al. Checkmate 577: health-related quality of life (HRQOL) in a randomized, double-blind phase III study of nivolumab (NIVO) versus placebo (PBO) as adjuvant treatment in patients (pts) with resected esophageal or gastroesophageal junction cancer (EC/GEJC) [abstract]. J Clin Oncol 2021;39(Suppl):Abstract 167.

35. Reynolds JV, Preston SR, O'Neill B, et al. Neo-AEGIS (neoadjuvant trial in adenocarcinoma of the esophagus and esophago-gastric junction international study): preliminary results of phase III RCT of CROSS versus perioperative chemotherapy (modified MAGIC or FLOT protocol). (NCT01726452) [abstract]. J Clin Oncol 2021;39(Suppl):Abstract 4004.

36. Hoeppner J, Lordick F, Brunner T, et al. ESOPEC: prospective randomized controlled multicenter phase III trial comparing perioperative chemotherapy (FLOT protocol) to neoadjuvant chemoradiation (CROSS protocol) in patients with adenocarcinoma of the esophagus (NCT02509286). BMC Cancer 2016;16:503.
37. Bang YJ, Van Cutsem E, Fuchs CS, et al. KEYNOTE-585: phase III study of perioperative chemotherapy with or without pembrolizumab for gastric cancer. Future Oncol 2019;15:943-952.

38. Janjigian YY, Cutsem EV, Muro K, et al. MATTERHORN: efficacy and safety of neoadjuvant-adjuvant durvalumab and FLOT chemotherapy in resectable gastric and gastroesophageal junction cancer-a randomized double-blind, placebo-controlled, phase 3 study [abstract]. J Clin Oncol 2021;39(Suppl):Abstract TPS4151.

39. Al-Batran SE, Pauligk C, Hofheinz R, et al. Perioperative atezolizumab in combination with FLOT versus FLOT alone in patients with resectable esophagogastric adenocarcinoma: DANTE, a randomized, open-label phase II trial of the German Gastric Group of the AIO and the SAKK [abstract]. J Clin Oncol 2019;37(Suppl):Abstract TPS4142.

40. Terashima M, Kim YW, Yeh TS, et al. ATTRACTION-05 (ONO-4538-38/ BMS CA209844): a randomized, multicenter, double-blind, placebo- controlled phase 3 study of nivolumab (nivo) in combination with adjuvant chemotherapy in stage III gastric and esophagogastric junction (G/EGJ) cancer. Ann Oncol 2017;28:v266-267.

41. Eads JR, Weitz M, Gibson MK, et al. A phase II/III study of perioperative nivolumab and ipilimumab in patients (pts) with locoregional esophageal (E) and gastroesophageal junction (GEJ) adenocarcinoma: a trial of the ECOG-ACRIN Cancer Research Group (EA2174) [abstract]. J Clin Oncol 2020;38(Suppl):Abstract TPS4651.

42. Janjigian YY, Shitara K, Moehler M, et al. First-line nivolumab plus chemotherapy versus chemotherapy alone for advanced gastric, gastro-oesophageal junction, and oesophageal adenocarcinoma (CheckMate 649). Lancet 2021;398:27-40

43. Pietrantonio F, Miceli R, Raimondi A, et al. Individual patient data metaanalysis of the value of microsatellite instability as a biomarker in gastric cancer. J Clin Oncol 2019;37:3392-3400.

44. Fuchs CS, Doi T, Jang RW, et al. Safety and efficacy of pembrolizumab monotherapy in patients with previously treated advanced gastric and gastroesophageal junction cancer: phase 2 clinical KEYNOTE-059 trial. JAMA Oncol 2018;4:e180013.

45. Shitara K, Van Cutsem E, Bang YJ, et al. Efficacy and safety of pembrolizumab or pembrolizumab plus chemotherapy vs chemotherapy alone for patients with first-line, advanced gastric cancer: the KEYNOTE-062 phase 3 randomized clinical trial. JAMA Oncol 2020;6:1571-1580.

46. Bang YJ, Van Cutsem E, Feyereislova A, et al. Trastuzumab in combination with chemotherapy versus chemotherapy alone for treatment of HER2-positive advanced gastric or gastro-oesophageal junction cancer (ToGA). Lancet 2010;376:687-697.

47. Rivera F, Izquierdo-Manuel M, García-Alfonso P, et al. Perioperative trastuzumab, capecitabine and oxaliplatin in patients with HER2-positive resectable gastric or gastro-oesophageal junction adenocarcinoma: NEOHX phase II trial. Eur J Cancer 2021;145:158-167.

48. Hofheinz RD, Hegewisch-Becker S, Kunzmann V, et al. Trastuzumab in combination with 5-fluorouracil, leucovorin, oxaliplatin and docetaxel as perioperative treatment for patients with human epidermal growth factor receptor 2-positive locally advanced esophagogastric adenocarcinoma. Int J Cancer 2021;149:1322-1331.

49. Abali H, Yalcin S, Onal HC, et al. A phase II study of the combination of oxaliplatin, capecitabine, and trastuzumab and chemoradiotherapy in the adjuvant setting in operated patients with HER2-positive gastric or gastroesophageal junction cancer (TOXAG Study): a Turkish Oncology Group study. Am J Clin Oncol 2021;44:301-307.

50. Schokker S, Molenaar RJ, Meijer SL, et al. Feasibility study of trastuzumab (T) and pertuzumab (P) added to neoadjuvant chemoradiotherapy (nCRT) in resectable HER2+ esophageal adenocarcinoma (EAC) patients (pts): the TRAP study [abstract]. J Clin Oncol 2018;36(Suppl):Abstract 4057.

51. Hofheinz RD, Haag GM, Ettrich TJ, et al. Perioperative trastuzumab and pertuzumab in combination with FLOT versus FLOT alone for HER2-positive resectable esophagogastric adenocarcinoma: final results of the PETRARCA multicenter randomized phase II trial of the AIO [abstract]. J Clin Oncol 2020;38(Suppl):Abstract 4502.

52. Ilson D, Moughan J, Safran H, et al. O-10 trastuzumab with trimodality treatment of esophageal adenocarcinoma with HER2 overexpression: NRG Oncology/RTOG 1010 [abstract]. Ann Oncol 2020; 31:Abstract 235.

53. Wagner AD, Grabsch HI, Mauer M, et al. EORTC-1203-GITCG - the "INNOVATION"-trial: effect of chemotherapy alone versus chemotherapy plus trastuzumab, versus chemotherapy plus trastuzumab plus pertuzumab, in the perioperative treatment of HER2 positive, gastric and gastroesophageal junction adenocarcinoma on pathologic response rate. BMC Cancer 2019;19:494 